\title{
Thermoelectric Properties of Hot-pressed Boron Suboxide $\left(\mathrm{B}_{6} \mathrm{O}\right)$
}

\author{
Takaya Akashi, Tsuyoshi Itoh ${ }^{* 1}$, Itaru Gunjishima ${ }^{* 2}$, Hiroshi Masumoto and Takashi Goto \\ Institute for Materials Research, Tohoku University, Sendai 980-8577, Japan
}

Boron suboxide $\left(\mathrm{B}_{6} \mathrm{O}\right)$ sintered bodies were prepared by a solid state reaction and a hot pressing method. The thermoelectric properties of $\mathrm{B}_{6} \mathrm{O}$ were compared with those of $\mathrm{B}_{4} \mathrm{C}$. The electrical conductivity was smaller than that of $\mathrm{B}_{4} \mathrm{C}$, and the Seebeck coefficient was twice as large as that of $\mathrm{B}_{4} \mathrm{C}$ indicating p-type conduction. The hopping conduction of electronic charge carriers was suggested from the temperature dependencies of the electrical conductivity and mobility. The thermal conductivity was greater than that of $\mathrm{B}_{4} \mathrm{C}$. The thermoelectric dimensionless figure-of-merit increased with increasing temperature, and was $0.62 \times 10^{-3}$ at $1000 \mathrm{~K}$. This value was almost in agreement with that of $\mathrm{B}_{4} \mathrm{C}$.

(Received March 11, 2002; Accepted May 27, 2002)

Keywords: boron suboxide, ichosahedral structure, thermoelectric property, Seebeck coefficient, electrical conductivity, thermal conductivity

\section{Introduction}

Boron-rich borides are promising as high-temperature thermoelectric materials. They have moderately high electrical conductivity, anomalously large Seebeck coefficient and low thermal conductivity as have been reported for boron carbide, ${ }^{1-6)} \alpha-\mathrm{AlB}_{12}{ }^{7,8)}$ and $\mathrm{B}_{12} \mathrm{Si}{ }^{9)}$

Among these boron-rich borides, boron carbide has been most widely studied. Figure 1 illustrates schematic crystal structures of $\mathrm{B}_{4} \mathrm{C}$ and $\mathrm{B}_{6} \mathrm{O}$. Boron carbide consists of $\mathrm{B}_{12}$ or $\mathrm{B}_{11} \mathrm{C}$ icosahedrons at the vertices of a rhombohedral unit cell and three-atom chain of $\mathrm{CBC}$ or $\mathrm{CBB}$ at the center of the rhombohedron. ${ }^{10-16)}$ Boron carbide has a wide nonstoichiometric composition region from $\mathrm{B}_{4} \mathrm{C}$ to $\mathrm{B}_{10.5} \mathrm{C}$ with different $\mathrm{B}$ to $\mathrm{C}$ ratio in the icosahedrons and three-atom chains. ${ }^{12,14,16)}$ Carbon-saturated boron carbide, $\mathrm{B}_{4} \mathrm{C}\left(\mathrm{B}_{12} \mathrm{C}_{3}\right)$, consists of $\mathrm{B}_{11} \mathrm{C}$ icosahedrons and $\mathrm{CBC}$ three atomic chains $\left(\mathrm{B}_{11} \mathrm{C}-\mathrm{CBC}\right) .{ }^{11,12,14)}$ It is well-understood that the thermoelectric properties of boron carbide change depending on the non-stoichiometric composition. The structure and properties of $B_{13} C_{2}$ has been particularly investigated in detail because $\mathrm{B}_{13} \mathrm{C}_{2}$ has greatest thermoelectric performance. ${ }^{3)}$ These boron carbides are p-type semiconductor, and the bipolaron hopping between $\mathrm{B}_{11} \mathrm{C}$ icosahedrons has been proposed to explain the large p-type Seebeck coefficient and small carrier mobility. ${ }^{17,18)}$

On the other hand, boron suboxide $\left(\mathrm{B}_{6} \mathrm{O}\right)$ consists of $\mathrm{B}_{12}$ icosahedrons and $\mathrm{O}-\mathrm{O}$ two-atom chain ${ }^{19-21)}$ as shown in Fig. 1(b). The structure of $\mathrm{B}_{6} \mathrm{O}$ is almost the same as that of $\mathrm{B}_{4} \mathrm{C}$ except that (1) the icosahedrons are pure $\mathrm{B}_{12}$, and (2) $\mathrm{O}-\mathrm{O}$ two-atom chains exist at the center of rhombohedrons. There is neither complicated substitution nor wide-ranged non-stoichiometry in $\mathrm{B}_{6} \mathrm{O}$. Therefore, it is useful to understand not only the characteristics of $\mathrm{B}_{6} \mathrm{O}$ but also that of $\mathrm{B}_{4} \mathrm{C}$ by comparing $\mathrm{B}_{6} \mathrm{O}$ and $\mathrm{B}_{4} \mathrm{C}$.

Table 1 summarizes the research on $\mathrm{B}_{6} \mathrm{O}$ published in the

\footnotetext{
${ }^{* 1}$ Graduate Student, Tohoku University, Present address: Honda R\&D Co., Ltd.

${ }^{* 2}$ Graduate Student, Tohoku University, Present address: Toyota Central
} R\&D Labs., Inc.
(1) $\mathrm{B}_{4} \mathrm{C}$

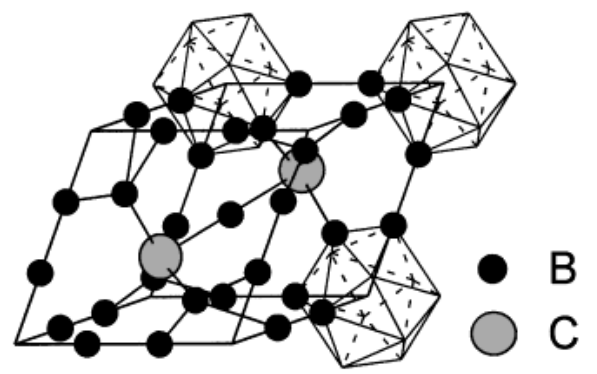

(2) $\mathrm{B}_{6} \mathrm{O}$

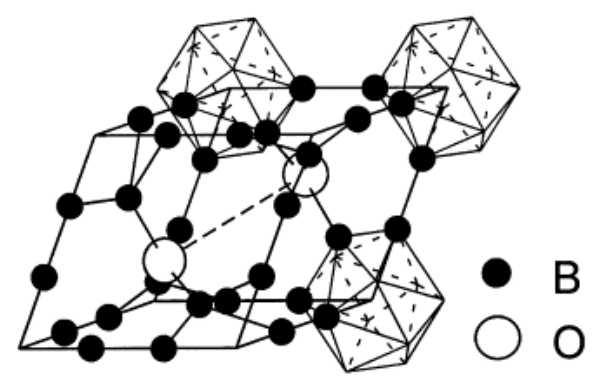

Fig. 1 Crystal Structure of (1) $\mathrm{B}_{4} \mathrm{C}$ and (2) $\mathrm{B}_{6} \mathrm{O}$.

past. The preparation method of $\mathrm{B}_{6} \mathrm{O}$ is classified into three categories as shown in Table 1: (1) solid state reaction between $\mathrm{B}$ and $\mathrm{B}_{2} \mathrm{O}_{3}$, (2) reduction of $\mathrm{B}_{2} \mathrm{O}_{3}$ and (3) oxidation of $\mathrm{B}$. The high vapor pressure of $\mathrm{B}_{2} \mathrm{O}_{3}$ at elevated temperatures would cause the $\mathrm{B}$ excess composition in the process of (1). The reductants such as $\mathrm{Si}$ or $\mathrm{Mg}$ would often remain in $\mathrm{B}_{6} \mathrm{O}$ as an impurity in the process (2). The oxidant such as $\mathrm{ZnO}$ would contaminate $\mathrm{B}_{6} \mathrm{O}$ in the process (3). Several researchers have reported the crystal structure ${ }^{19-25,30,31)}$ and some mechanical properties ${ }^{26,30,32,36)}$ of $\mathrm{B}_{6} \mathrm{O}$. Since $\mathrm{B}_{6} \mathrm{O}$ is strong covalent nature and easy to decompose at high temperature more than $1973 \mathrm{~K},{ }^{23)}$ dense $\mathrm{B}_{6} \mathrm{O}$ bodies can be hardly obtained. In the present study, moderately dense $\mathrm{B}_{6} \mathrm{O}$ bodies were prepared by a hot-pressing method. Their electrical conductivity, Seebeck coefficient and thermal conductivity were 
Table 1 Literature data of boron suboxides (in chronological order).

\begin{tabular}{|c|c|c|c|}
\hline Methods & Raw materials & Evaluated properties & Ref. \\
\hline No detail & No detail & $a, b, c, d_{h k l}$ & 22) \\
\hline Solid state reaction & $\mathrm{B}+\mathrm{B}_{2} \mathrm{O}_{3}, \mathrm{~B}_{2} \mathrm{O}_{3}+\mathrm{Si}$ & $a, b, c, d_{h k l}, I / I_{0}$ & 23) \\
\hline Solid state reaction & $\mathrm{B}+\mathrm{B}_{2} \mathrm{O}_{3}$ & $a, b, c, d_{h k l}, I / I_{0}$ & 24) \\
\hline Fusion, Plasma arc & $\mathrm{B}_{2} \mathrm{O}_{3}+\mathrm{Mg}, \mathrm{B}+\mathrm{B}_{2} \mathrm{O}_{3}$ & $a, b, c, d_{h k l}, I / I_{0}$ & 25) \\
\hline Hot press & No detail & Mechanical properties, $\kappa$ & 26) \\
\hline Hot press & $\mathrm{B}+\mathrm{B}_{2} \mathrm{O}_{3}, \mathrm{~B}+\mathrm{ZnO}$ & Reaction, Sinterabilitty & 27) \\
\hline Oxidation & $\mathrm{B}+\mathrm{ZnO}$ & Crystal structure & 20) \\
\hline Hot press & $\mathrm{B}+\mathrm{B}_{2} \mathrm{O}_{3}$ & Thermodynamic properties & 28) \\
\hline No detail & No detail & Thermoelastic properties & 29) \\
\hline Solid state reaction & amo.-B + ZnO & Crystal structure & 21) \\
\hline Reaction sintering & amo.-B, $\alpha-\mathrm{B}, \mathrm{B}_{2} \mathrm{O}_{3}$ & Crystal structure, Bulk Modulous & 30) \\
\hline Solid state reaction & amo.-B, $\alpha-\mathrm{B}, \mathrm{B}_{2} \mathrm{O}_{3}$ & Crystal structure & 31) \\
\hline Solid state reaction & ${ }^{10} \mathrm{~B},{ }^{11} \mathrm{~B}, \mathrm{~B}(\mathrm{OH})_{3}$, etc. & Raman spectra & 15) \\
\hline HP-HT synthesis & $\mathrm{B}+\mathrm{B}_{2} \mathrm{O}_{3}$ & Morphology, Structure & 33) \\
\hline HP-HT synthesis & $\mathrm{B}+\mathrm{B}_{2} \mathrm{O}_{3}$ & Morphology, Structure & 34) \\
\hline HP-HT synthesis & $\mathrm{B}+\mathrm{B}_{2} \mathrm{O}_{3}$ & Morphology, $\Delta G_{\mathrm{f}}$ & 35) \\
\hline Solid state reaction, Sintering & $\mathrm{B}+\mathrm{ZnO}$ & Mechanical Properties & 36) \\
\hline Pulsed laser deposition & $\mathrm{B}+\mathrm{B}_{2} \mathrm{O}_{3}$ & Infrared spectra, Raman spectra & 37) \\
\hline Pulsed laser deposition & $\mathrm{B}+\mathrm{B}_{2} \mathrm{O}_{3}$ & TEM, SEM & 38) \\
\hline High-pressure sintering & $\left(\mathrm{B}+\mathrm{B}_{2} \mathrm{O}_{3}\right)+\mathrm{c}-\mathrm{BN}$ & Mechanical Properties & 39) \\
\hline High-pressure sintering & $\left(\mathrm{B}+\mathrm{B}_{2} \mathrm{O}_{3}\right)+\mathrm{B}_{4} \mathrm{C}$ & Mechanical Properties & 40) \\
\hline
\end{tabular}

$a, b, c$ : Lattice parameters, $d_{h k l}$ : interplanar spacing, $I / I_{0}$ : Relative diffraction intensity, $\kappa$ : Thermal conductivity, amo.: Amorphous, HP-HT synthesis: High-pressure, high-temperature synthesis, $\Delta G_{\mathrm{f}}$ : Gibbs energy of formation, TEM: Transmission electron microscope, SEM: Scanning electron microscopy.

investigated, and were mainly compared with those of $\mathrm{B}_{4} \mathrm{C}$ having similar porosity of $\mathrm{B}_{6} \mathrm{O}$.

\section{Experimental Procedure}

$\beta$-B powder (High purity Chemical Laboratory, 99\%) and amorphous $\mathrm{B}_{2} \mathrm{O}_{3}$ powder (Wako Pure Chemical, 99\%) were mixed in the molar ratio of $10: 1(\mathrm{~B}: \mathrm{O}=4: 1)$ under the $\mathrm{B}_{2} \mathrm{O}_{3}$ excess condition. The mixed powder was pressed into diskshaped pellets at $30 \mathrm{MPa}$, and reacted at $1673 \mathrm{~K}$ for $14.4 \mathrm{ks}$ in flowing Ar gas. The pellets were pulverized and heated again at the same condition. This procedure was repeated several times and obtained $\mathrm{B}_{6} \mathrm{O}$ powder in single phase, and the remaining $\mathrm{B}_{2} \mathrm{O}_{3}$ was carefully removed by this heat treatments. The $\mathrm{B}_{6} \mathrm{O}$ powder was hot-pressed at $1873 \mathrm{~K}, 62 \mathrm{MPa}$ for $18 \mathrm{ks}$ in flowing Ar gas with being covered by BN powder to avoid the reaction between $\mathrm{B}_{6} \mathrm{O}$ powder and a carbon mold.

Powder X-ray diffraction was carried out to determine the phase and lattice parameters. Pycnometry in distilled water was used to measure the density of $\mathrm{B}_{6} \mathrm{O}$ powder. An Archimedian method was applied to determine the porosity of $\mathrm{B}_{6} \mathrm{O}$ sintered bodies.

Hot-pressed $\mathrm{B}_{6} \mathrm{O}$ bodies were cut into three sizes for measurement $\left(3 \times 3 \times 12 \mathrm{~mm}^{3}\right.$ for Seebeck coefficient and electrical conductivity, $\phi 10 \times 1.5 \mathrm{~mm}^{3}$ for thermal conductivity, and $3 \times 6 \times 0.5 \mathrm{~mm}^{3}$ for Hall coefficient). The Seebeck coefficient $(\alpha)$ was determined from the slope of the linear relationship between thermoelectric power and temperature difference in Ar gas at 300 to $1000 \mathrm{~K}$. The electrical conductivity $(\sigma)$ was measured by a d.c. four-probe method in Ar gas at 300 to $1000 \mathrm{~K}$. The Hall coefficient measurement was carried out by a Van der Pauw method in vacuum at 300 to $1000 \mathrm{~K}$. The thermal conductivity $(\kappa)$ was measured by a laser flush method (TC-7000, Shinku Riko) in vacuum at 290 to $1060 \mathrm{~K}$.

The figure-of-merit $(Z)$ was calculated using eq. (1) from Seebeck coefficient $(\alpha)$, electrical conductivity $(\sigma)$ and thermal conductivity $(\kappa)$.

$$
Z T=\alpha^{2} \sigma T / \kappa
$$

\section{Results and Discussion}

Figure 2 presents the powder X-ray diffraction pattern for a hot-pressed $\mathrm{B}_{6} \mathrm{O}$ body. Every peak was identified as $\mathrm{B}_{6} \mathrm{O}$ and no trace of $\mathrm{B}_{2} \mathrm{O}_{3}$ was observed. The lattice parameters of $\mathrm{B}_{6} \mathrm{O}$ were determined as $a=0.538 \mathrm{~nm}$ and $c=1.233 \mathrm{~nm}$ (in hexagonal expression), and the density of $\mathrm{B}_{6} \mathrm{O}\left(\rho_{\text {obs }}\right)$ was $2.587 \mathrm{Mgm}^{-3}$, meaning the porosity of $33 \%$. Rizzo et $a l .{ }^{23)}$ reported that $\mathrm{B}_{6} \mathrm{O}$ evaporated significantly at more than $1973 \mathrm{~K}$. The high vapor pressure of $\mathrm{B}_{2} \mathrm{O}_{3}$ which formed by the decomposition of $\mathrm{B}_{6} \mathrm{O}$ into $\mathrm{B}$ and $\mathrm{B}_{2} \mathrm{O}_{3}$ could be a main reason for the difficulty of sintering.

Figure 3 shows the temperature dependence of the Seebeck coefficient for the hot-pressed $\mathrm{B}_{6} \mathrm{O}$, comparing with that of $\mathrm{B}_{4} \mathrm{C}^{1,3-6)}$ whose porosity is indicated in parentheses. Significant effect of density on the Seebeck coefficient was not observed. The positive Seebeck coefficient of $\mathrm{B}_{6} \mathrm{O}$ means that the carrier in $\mathrm{B}_{6} \mathrm{O}$ is hole. The Seebeck coefficient of $\mathrm{B}_{6} \mathrm{O}$ increased with increasing temperature. The Seebeck coeffi- 


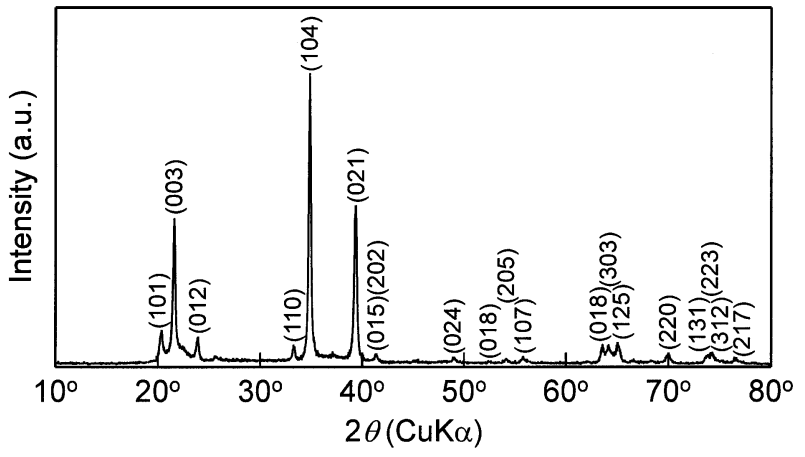

Fig. 2 Powder $\mathrm{X}$-ray diffraction pattern of hot-pressed $\mathrm{B}_{6} \mathrm{O}$.

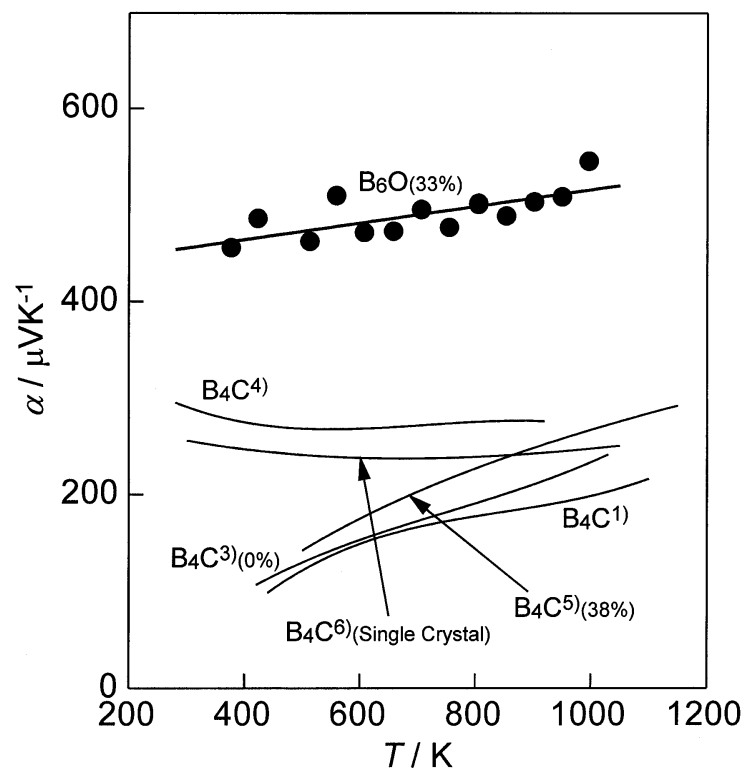

Fig. 3 Temperature dependence of Seebeck coefficient for hot-pressed $\mathrm{B}_{6} \mathrm{O}$. (Numerals in parentheses mean porosity of the specimens).

cient of $\mathrm{B}_{6} \mathrm{O}$ was twice as great as that of $\mathrm{B}_{4} \mathrm{C}$ and reached to $500 \mu \mathrm{VK}^{-1}$ at $1000 \mathrm{~K}$. Although the Seebeck coefficient of some $\mathrm{B}_{4} \mathrm{C}$ was independent of temperature, it generally increased with increasing temperature. Wood et al. ${ }^{1)}$ proposed a model to explain the temperature dependence of $\mathrm{B}_{4} \mathrm{C}$ using small polaron hopping conduction mechanism, and gave eq. (2).

$$
\alpha=\left(T \Delta S+E_{\mathrm{T}}\right) / q T=A+B T
$$

where $\Delta S$ is average charge of entropy, $E_{\mathrm{T}}$ the average vibrational energy, $q$ the charge of carrier, and $A$ and $B$ constants. The temperature dependence of Seebeck coefficient for $\mathrm{B}_{6} \mathrm{O}$ may be explained by eq. (2). This might be also verified by small mobility as shown later.

Figure 4 shows the temperature dependence of electrical conductivity for the hot-pressed $\mathrm{B}_{6} \mathrm{O}$ and $\mathrm{B}_{4} \mathrm{C} .{ }^{1,3,5,6)}$ The electrical conductivity of $\mathrm{B}_{6} \mathrm{O}$ was $1.1 \times 10^{2} \mathrm{Sm}^{-1}$ at $1020 \mathrm{~K}$. The electrical conductivity of fully dense $\mathrm{B}_{6} \mathrm{O}$ will be greater, because those of $\mathrm{B}_{4} \mathrm{C}$ were affected by porosity. The electrical conductivity of $\mathrm{B}_{6} \mathrm{O}$ increased with increasing temperature. The temperature dependence was similar with that of $\mathrm{B}_{4} \mathrm{C},{ }^{1)}$ obeying eq. (3) for a hopping conduction:

$$
\sigma=(C / T) \exp \left(-E_{\mathrm{a}} / k_{\mathrm{B}} T\right)
$$

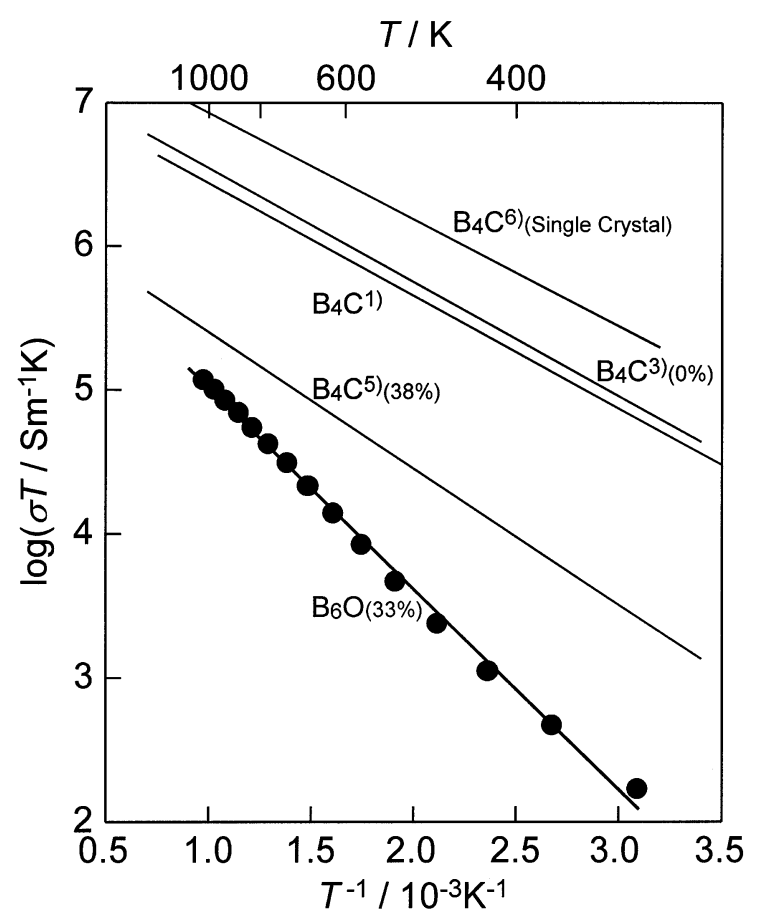

Fig. 4 Temperature dependence of the electrical conductivity for hot-pressed $\mathrm{B}_{6} \mathrm{O}$. (Numerals in parentheses mean porosity of the specimens).

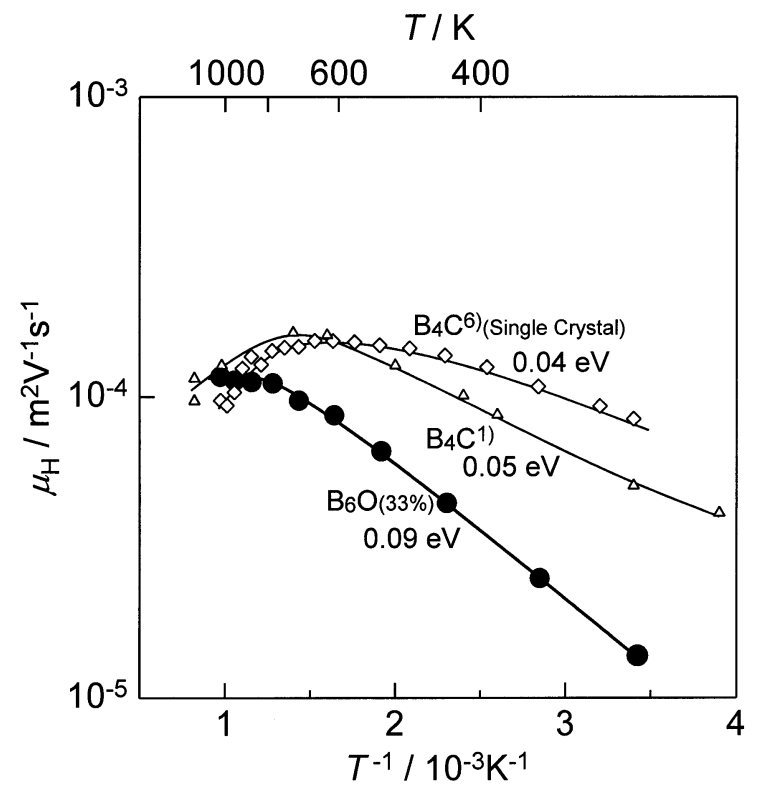

Fig. 5 Temperature dependence of Hall mobility for hot-pressed $\mathrm{B}_{6} \mathrm{O}$. (Numerals in parentheses mean porosity of the specimens).

where $C$ is a constant, $k_{\mathrm{B}}$ is Boltzmann constant, and $E_{\mathrm{a}}$ is activation energy for electrical conductivity. The activation energy for $\mathrm{B}_{6} \mathrm{O}, E_{\mathrm{a}}$, was $0.28 \mathrm{eV}$. This value was greater than those for $\mathrm{B}_{4} \mathrm{C}(0.14$ to $0.18 \mathrm{eV})$.

Figure 5 demonstrates the temperature dependence of Hall mobility for the hot-pressed $\mathrm{B}_{6} \mathrm{O}$. The Hall mobility of $\mathrm{B}_{6} \mathrm{O}$ increased from $10^{-5}$ to $10^{-4} \mathrm{~m}^{2} \mathrm{~V}^{-1} \mathrm{~s}^{-1}$ with increasing temperature from 290 to $800 \mathrm{~K}$. The mobility of non-generated semiconductor typically for $\mathrm{Si}$ single crystal at $300 \mathrm{~K}$ is $8 \times 10^{-2} \mathrm{~m}^{2} \mathrm{~V}^{-1} \mathrm{~s}^{-1}$ which decreased with increasing temperature. ${ }^{41)}$ The mobility of $\mathrm{B}_{6} \mathrm{O}$ and $\mathrm{B}_{4} \mathrm{C}$ was $1 / 10000$ to $1 / 1000$ times less than that of $\mathrm{Si}$, and had opposite temperature de- 


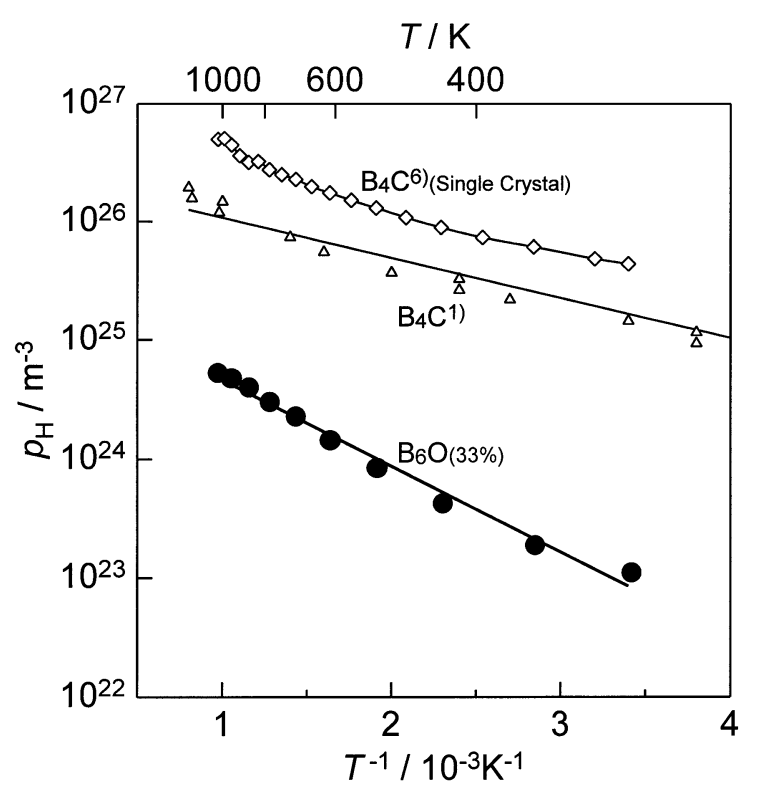

Fig. 6 Temperature dependence of Hall carrier concentration for hot-pressed $\mathrm{B}_{6} \mathrm{O}$. (Numerals in parentheses mean porosity of the specimens).

pendence to Si. The significantly small mobility and its positive temperature dependence are indicative of the small polaron hopping conduction, because the carriers should be mobile with dragging lattice vibration (i.e. phonon) and would be thermally activated at higher temperatures by phonons. The activation energy of $0.09 \mathrm{eV}$ for $\mathrm{B}_{6} \mathrm{O}$ was greater than that of $0.05 \mathrm{eV}$ for $\mathrm{B}_{4} \mathrm{C}$, suggesting more significant nature of small polaron hopping than that of $\mathrm{B}_{4} \mathrm{C}$.

Figure 6 demonstrates the temperature dependence of carrier concentration for the hot-pressed $\mathrm{B}_{6} \mathrm{O}$. The carrier concentration of $\mathrm{B}_{6} \mathrm{O}$ was one to two orders of magnitude smaller than that in $\mathrm{B}_{4} \mathrm{C}$ and increased with increasing temperature. The positive value of Hall coefficient was consistent with the polarity of Seebeck coefficient. The hole concentration of $\mathrm{B}_{6} \mathrm{O}$ was smaller than that of $\mathrm{B}_{4} \mathrm{C}$, which would justify the greater Seebeck coefficient of $\mathrm{B}_{6} \mathrm{O}$ than that of $\mathrm{B}_{4} \mathrm{C}$.

Figure 7 shows the temperature dependence of thermal conductivity for the hot-pressed $\mathrm{B}_{6} \mathrm{O}$, comparing with those for reported values of $\mathrm{B}_{6} \mathrm{O}^{26)}$ and $\mathrm{B}_{4} \mathrm{C}^{2,5,6)}$ The thermal conductivity of the hot-pressed $\mathrm{B}_{6} \mathrm{O}$ decreased with increasing temperature. This trend was similar to those of reported values, indicating that the transport of phonons are dominant. The thermal conductivity of hot-pressed $\mathrm{B}_{6} \mathrm{O}$ was slightly smaller than the reported value of $\mathrm{B}_{6} \mathrm{O}$ (10\% porosity) $\left.{ }^{26}\right)$ probably due to the effect of porosity. Sintered $\mathrm{B}_{4} \mathrm{C}(38 \%$ porosity $)^{5)}$ showed smaller thermal conductivity than the hotpressed $\mathrm{B}_{6} \mathrm{O}$ (33\% porosity). Since the porosity is similar between these two specimens, the thermal conductivity of $\mathrm{B}_{6} \mathrm{O}$ may be basically greater than that of $\mathrm{B}_{4} \mathrm{C}$. Single crystal $\mathrm{B}_{4} \mathrm{C}$ had much greater thermal conductivity than those of sintered $\mathrm{B}_{4} \mathrm{C}$. The grain boundary and porosity could decrease the thermal conductivities of $\mathrm{B}_{4} \mathrm{C}$ and $\mathrm{B}_{6} \mathrm{O}$. Further study should be necessary to prepare highly dense $\mathrm{B}_{6} \mathrm{O}$ to understand the intrinsic nature of $\mathrm{B}_{6} \mathrm{O}$.

Figure 8 presents the temperature dependence of dimensionless figure-of-merit $(Z T)$ for the hot-pressed $\mathrm{B}_{6} \mathrm{O}$ comparing with those reported for $\mathrm{B}_{4} \mathrm{C}$ and $\mathrm{B}_{6} \mathrm{O}$. The $Z T$ value for the

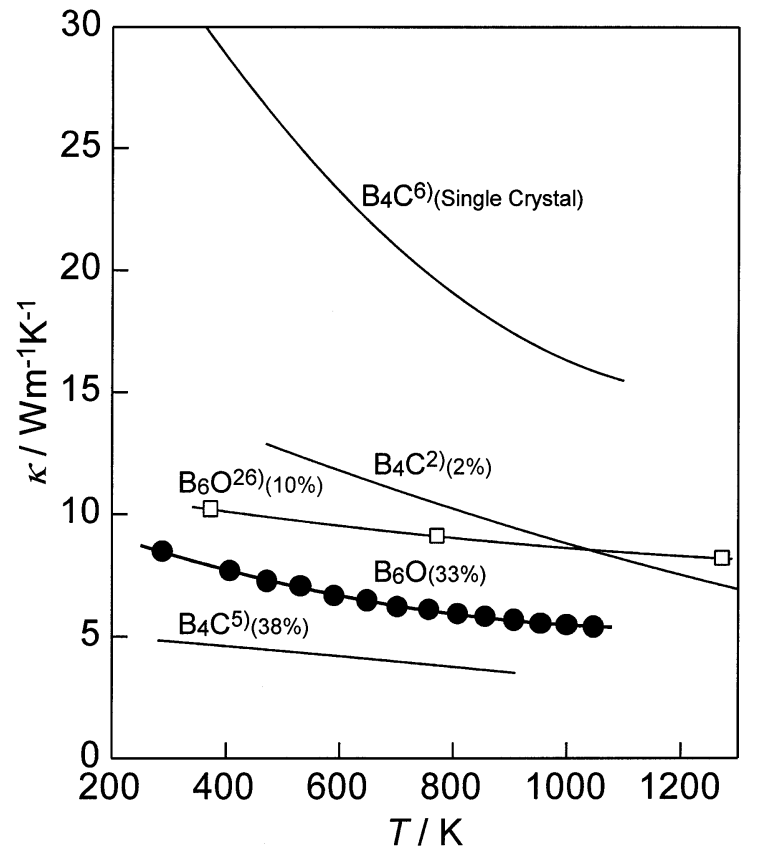

Fig. 7 Temperature dependence of thermal conductivity for hot-pressed $\mathrm{B}_{6} \mathrm{O}$. (Numerals in parentheses mean porosity of the specimens).

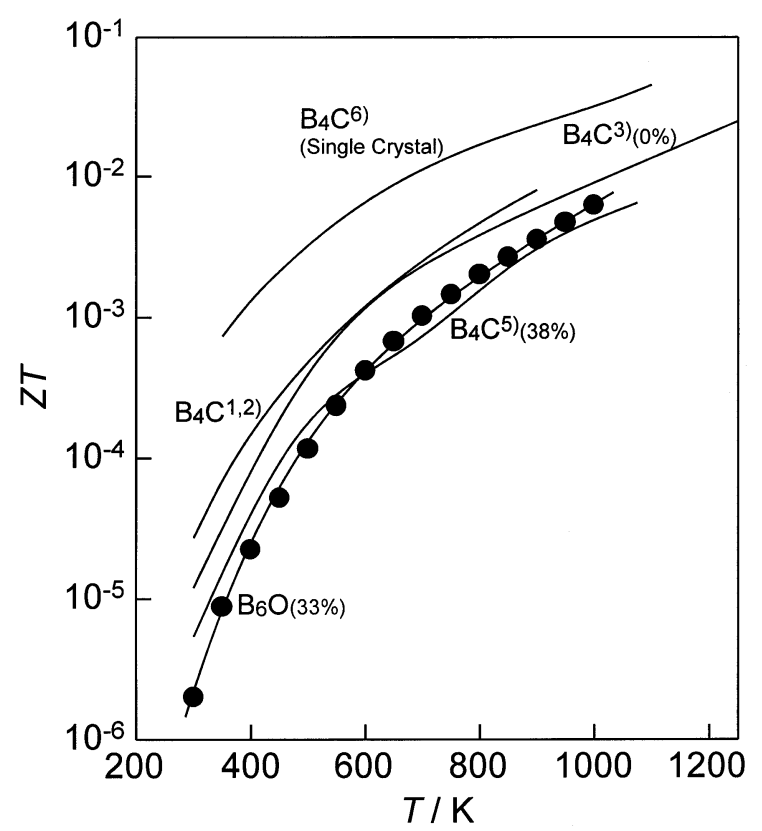

Fig. 8 Temperature dependence of dimension-less figure-of-merit for hot-pressed $\mathrm{B}_{6} \mathrm{O}$. (Numerals in parentheses mean porosity of the specimens).

hot-pressed $\mathrm{B}_{6} \mathrm{O}$ increased with temperature, and reached to $0.62 \times 10^{-3}$ at $1000 \mathrm{~K}$. This value was almost in agreement with that of $\mathrm{B}_{4} \mathrm{C},{ }^{5)}$ having the similar porosity.

\section{Conclusion}

$\mathrm{B}_{6} \mathrm{O}$ bodies with $33 \%$ porosity in single phase were prepared by hot-pressing. Lattice parameters were $a=$ $0.538 \mathrm{~nm}, c=1.233 \mathrm{~nm}$. The thermoelectric properties of the hot-pressed $\mathrm{B}_{6} \mathrm{O}$ were compared with those of $\mathrm{B}_{4} \mathrm{C}$.

(1) The electrical conductivity is lower than that of $\mathrm{B}_{4} \mathrm{C}$. The small mobility and its positive temperature dependence 
suggests the small polaron hopping conduction.

(2) The Seebeck coefficient is twice as great as that of $\mathrm{B}_{4} \mathrm{C}$.

(3) The thermal conductivity may be greater than that of $\mathrm{B}_{4} \mathrm{C}$.

(4) The dimension-less figure-of-merit (ZT) increases with increasing temperature, and reaches to $0.62 \times 10^{-3}$ at $1000 \mathrm{~K}$. This value is almost in agreement with that of $\mathrm{B}_{4} \mathrm{C}$ having the similar porosity.

\section{REFERENCES}

1) C. Wood and D. Emin: Phys. Rev. B 29 (1984) $4582-4587$.

2) C. Wood, D. Emin and P. E. Gray: Phys. Rev. B 31 (1985) 6811-6814.

3) M. Bouchacourt and F. Thevenot: J. Mater. Sci. 20 (1985) 1237-1247.

4) T. L. Aselage, D. Emin, S. S. McCready and R. V. Duncan: Phys. Rev. Lett. 81 (1998) 2316-2319.

5) K. Cai, C. Nan and X. Min: Mater. Sci. Eng. B 67 (1999) 102-107.

6) I. Gunjishima, T. Akashi and T. Goto: Mater. Trans. 42 (2001) 14451450 .

7) O. A. Golikova, V. K. Zaitsev, A. V. Petrov, L. S. Stil'bans and E. N. Tkalenko: Sov. Phys.-Semicond. 6 (1973) 1488-1491.

8) O. A. Golikova, V. K. Zaitsev, V. M. Orlov, A. V. Petrov, L. S. Stilbans and E. N. Tkalenko: Phys. Status. Solidi. (a) 21 (1974) 405-412.

9) J. M. Darolles, T. Lepetre and J. M. Dusseau: Phys. Status. Solidi. (a) 58 (1980) K71-K75.

10) A. Kirfel, A. Gupta and G. Will: Acta Cryst. B35 (1979) 1052-1059.

11) D. M. Bylander and L. Kleinman: Phys. Rev. B 43 (1991) 1487-1491.

12) D. Emin: Phys. Rev. B 38 (1988) 6041-6055.

13) D. R. Tallant, T. L. Aselage, A. N. Campbell and D. Emin: Phys. Rev. B 40 (1989) 5649-5656.

14) U. Kuhlmann and H. Werheit: Solid State Commun. 83 (1992) 849852.

15) T. L. Aselage, D. R. Tallant and D. Emin: Phys. Rev. B 56 (1997) 3122 3129.

16) M. Beauvy: J. Less-Common Met. 90 (1983) 169-175.

17) D. Emin: Boron-Rich Solids, AIP Conf. Proc. 231 (1990) 65-76.

18) G. A. Samara, H. L. Tardy, E. L. Venturini, T. L. Aselage and D. Emin:
Phys. Rev. B 48 (1993) 1468-1477.

19) H. Bolmgren, T. Lundstrom and S. Okada: Boron-Rich Solids, AIP Conf. Proc. 231 (1990) 197-200.

20) I. Higashi, M. Kobayashi, J. Bernhard, C. Brodhag and F. Thevenot: Boron-Rich Solids, AIP Conf. Proc. 231 (1990) 201-204.

21) M. Kobayashi, I. Higashi, C. Brodhag and F. Thevenot: J. Mater. Sci. 28 (1993) 2129-2134.

22) R. A. Pasternak: Acta Cryst. 12 (1959) 612-613.

23) H. F. Rizzo, W. C. Simmons and H. O. Bielstein: J. Electrochem. Soc. 109 (1962) 1079-1082.

24) E. V. Zubova and K. P. Burdina: Sov. Phys. Dokl. 16 (1971) 317-318.

25) P. M. Bills and D. Lewis: J. Less-Common Met. 45 (1976) 343-345.

26) I. A. Bairamashvili, G. I. Kalandadze, A. M.Eristavi, J. Sh. Jobava, V. V. Chotulidi and Yu. I. Saloev: J. Less-Common Met. 67 (1979) 455-461.

27) C. Brodhag and F. Thevenot: J. Less-Common Met. 117 (1986) 1-6.

28) G. V. Tsagareishvili, D. Sh. Tsagareishvili, M. Ch. Tushishvili, I. S. Omiadze, V. N. Naumov and A. B. Tagaev: Boron-Rich Solids, AIP Conf. Proc. 231 (1990) 384-391.

29) D. Sh. Tsagareishvili, M. Ch. Tushishvili and G. V. Tsagareishvili: Boron-Rich Solids, AIP Conf. Proc. 231 (1990) 392-395.

30) T. Lundstrom: J. Solid State Chem. 133 (1997) 88-92.

31) M. Olofsson and T. Lundstrom: J. Alloy. Compd. 257 (1997) 91-95.

32) C. Doughty, S. M. Gorbatkin, T. Y. Tsui, G. M. Pharr and D. L. Medlin: J. Vac. Sci. Technol. A 15 (1997) 2623-2626.

33) H. Hubert, B. Devouard, L. A. J. Garvie, M. O'Keeffe, P. R. Buseck, W. T. Petuskey and P. F. McMillan: Nature 391 (1998) 376-378.

34) H. Hubert, L. A. J. Garvie, B. Devouard, P. R. Buseck, W. T. Petuskey and P. F. McMillan: Chem. Mater. 10 (1998) 1530-1537.

35) P. F. McMillan, H. Hubert, A. Chizmeshya, W. T. Petuskey, L. A. J. Garvie and B. Devouard: J. Solid State Chem. 147 (1999) 281-290.

36) I. O. Kayhan and O. T. Inal: J. Mater. Sci. 34 (1999) 4105-4120.

37) S. Yu, Y. Ji, T. Li, M. Han, G. Wang, X. Yuan, Z. Li and P. Chen: Solid State Commun. 115 (2000) 307-311.

38) S. Yu, G. Wang, S. Yin, Y. Zhang and Z. Liu: Phys. Lett. A 268 (2000) $442-447$.

39) H. Itoh, R. Yamamoto and H. Iwahara: J. Am. Ceram. Soc. 83 (2000) 501-506.

40) H. Itoh, I. Maekawa and H. Iwahara: J. Mater. Sci. 35 (2000) 693-698.

41) R. Kishore, P. Prakash, S. N. Singh and B. K. Das: J. Appl. Phys. 71 (1992) 4341-4343 